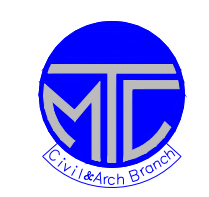

\title{
ICCAE
}

Military Technical College

Kobry Elkobbah,

Cairo, Egypt 7th International Conference

On Civil \& Architecture

Engineering

\section{THE EGYPTIAN - CANADIAN CONJUNCTION PROGRAM ON MITIGATION OF BLAST-LOADED STRUCTURE}

\author{
Col. Dr. A.F.Farage.
}

\begin{abstract}
Fortificated structures are subjected to severe loading conditions due to the effect of blast explosions. A choice is to be taken to replace existing structures or to upgrade using modern techniques. A comprehensive research program has been undertaken between the Egyptian and the Canadian parties. The main objectives of the conjunction program are to study the effect of blast loading on structural and structural elements. Blast mitigation system has been proposed to window-glassing and R.C. elements.
\end{abstract}

